\title{
Perbandingan Permen Karet Rasa Mint dengan Ondansentron 4 mg Intravena dalam Mengatasi Kejadian Mual Muntah Pascaoperasi Mastektomi
}

\author{
Nobelia Carnationi, ${ }^{1}$ Ezra Oktaliansah, ${ }^{2}$ Indriasari ${ }^{2}$ \\ ${ }^{1}$ Rumah Sakit Dr. Sutoyo Jakarta, ${ }^{2}$ Departemen Anestesiologi dan Terapi Intensif \\ Fakultas Kedokteran Universitas Padjadjaran/RSUP Dr. Hasan Sadikin Bandung
}

\begin{abstract}
Abstrak
Permen karet rasa mint dapat menstimulasi sefalik vagal yang mampu mencegah mual dan muntah. Penelitian ini bertujuan membandingkan permen karet rasa mint dengan ondansentron 4 mg terhadap mual muntah pascaoperasi. Metode penelitian adalah eksperimental secara acak terkontrol buta tunggal pada 46 wanita yang menjalani mastektomi terhadap wanita ( $>18$ tahun) yang mengalami mual dan muntah pascaoperasi di RSUP Dr. Hasan Sadikin Bandung pada bulan Februari-Juli 2019. Data perbaikan mual muntah dianalisis dengan uji chi kuadrat. Hasil perhitungan statistik menunjukkan kelompok permen karet rasa mint mampu mengatasi mual muntah lebih banyak dibanding dengan ondansentron (18 orang vs 9 orang) dengan perbedaan yang sangat bermakna $(\mathrm{p}<0.001)$. Simpulan penelitian adalah permen karet rasa mint mengatasi lebih banyak pasien yang mual muntah pascaoperasi mastektomi dibanding dengan ondansetron.
\end{abstract}

Kata kunci: Mastektomi, mual, muntah, ondansetron, permen karet

\section{Comparison between Mint Chewing Gum and 4 mg Intravenous Ondansentron in Nausea and Vomiting Treatment after Mastectomy}

\begin{abstract}
Mint flavored gum can stimulate the cephalic vagal that can eventually prevent nausea and vomiting. This study aimed to compare the use of mint flavored gum and $4 \mathrm{mg}$ ondansetron in treating post-operative vomiting. This was a single blind randomized experimental study conducted on 46 women ( $>18$ years old) underwent mastectomy who experienced post-operative vomiting in Dr. Hasan Sadikin General Hospital Bandung between February and July 2019. Data on postoperative nausea and vomiting were analyzed using chi square. The statistical results showed that the mint flavored gum had a significantly better ability in treating post-operative nausea and vomiting when compared to ondansetron (18 versus 9 person) $(\mathrm{p}<0.001)$. In conclusion, mint flavored gum has a better ability in postoperative nausea and vomiting treatment after mastectomy compared to ondansetron.
\end{abstract}

Key words: Gum, mastectomy, nausea, ondansetron,vomiting

Korespondensi: Nobelia Carnationi, dr, SpAn, Rumah Sakit Dr. Sutoyo, Jakarta, Jl. RC. Veteran Raya No.178, RT.9/RW.3, Bintaro, Kec. Pesanggrahan, Kota Jakarta Selatan, Daerah Khusus Ibukota Jakarta 12330, Tlpn (021) 7342012 Email: ferawatiardian@gmail.com 


\section{Pendahuluan}

Mual muntah pascaoperasi pada mastektomi mempunyai insidens cukup tinggi, yaitu $30-50 \%$, terutama pada 24 jam pertama pascaoperasi. Etiologi mual muntah pascaoperasi melibatkan berbagai faktor, antara lain faktor individual, anestesi dan jenis operasi. Mual muntah dapat menyebabkan dehidrasi, ketidakseimbangan elektrolit, terbukanya luka operasi, aspirasi cairan lambung, hipertensi, dan gangguan jalan napas yang mengancam nyawa. ${ }^{1,2}$

Upaya mengurangi maupun penanganan mual muntah pascaoperasi dapat dilakukan dengan beberapa strategi baik dengan terapi farmakologi atau nonfarmakologi (akupuntur dan penggunaan jahe) yang memiliki keuntungan harga murah, efek samping minimal, dan dapat diterima oleh pasien. ${ }^{2}$

Permen karet dengan aktivitas sham feeding-nya mengaktifasi refleks sefalik vagal yang sama dengan ketika kita memakan makanan dan menstimulasi motilitas dari duodenum, gaster, dan rektum. Permen karet meningkatkan konsentrasi gastrin serum, neurotensin dan polipeptida pankreas, menstimulasi motilitas duodenum, gaster, dan rektum, serta memicu motilitas intestinal.

Suatu studi menunjukkan perubahan pengosongan lambung sesudah empat jam memakan minyakpeppermint, didapatkan pada tahap awal terjadi pengosongan lambung yang lebih cepat menunjukkan minyak peppermint lag time 56,6 menit dibanding dengan kontrol 71,5 menit $(p=0,037)$. Penelitian tersebut menguatkan penelitian sebelumnya yang menunjukkan bahwa minyak pepermint memengaruhi motilitas gaster dan memiliki efek anti spastik pada perut, serta pemberian minyak peppermint menstimulasi pembukaan cincin pilorus yang dinilai menggunakan endoskopi. ${ }^{3}$

Pada saat ini masih sedikit penelitian mengenai efek permen karet rasa mint terhadap perbaikan mual muntah pascaoperasi sehingga penulis bermaksud meneliti hal tersebut. Penelitian ini bertujuan membandingkan permen karet rasa mint dengan ondansentron $4 \mathrm{mg}$ terhadap perbaikan mual muntah pascaoperasi.

\section{Subjek dan Metode}

Penelitian menggunakan desain penelitian uji klinis acak buta tunggal (single blind randomized controlled trial) yang ditujukan untuk menguji hipotesis pemberian permen karet rasa mint dapat mengatasi kejadian mual muntah pascaoperasi mastektomi yang lebih banyak dibanding dengan ondansetron $4 \mathrm{mg}$ intravena. Penelitian dilakukan setelah mendapatkan persetujuan dari Komite Etik Penelitian Kesehatan RSHS/Fakultas Kedokteran Universitas Padjadjaran. Penelitian dilakukan di kamar operasi (COT) lantai 3 RSUP Dr. Hasan Sadikin, Jalan Pasteur No. 38 Bandung dari Februari sampai Juli 2019.

Penentuan besar sampel dilakukan berdasar perhitungan perbedaan 2 rerata dengan taraf kepercayaan 95\% dan kuasa uji (power test) 90\%. Berdasar perhitungan didapatkan jumlah sampel minimal tiaptiap kelompok adalah 23 orang sehingga total sampel 2 kelompok adalah 46 orang. Pengambilan sampel dilakukan secara consecutive sampling dan alokasi subjek ke dalam salah satu kelompok dilakukan secara random blok permutasi.

Penelitian dilakukan di RSUP Dr. Hasan Sadikin Bandung pada bulan Februari hingga Juli 2019 setelah mendapatkan persetujuan dari Komite Etik Penelitian Kesehatan Rumah Sakit Dr. Hasan Sadikin Bandung/Fakultas Kedokteran Universitas Padjadjaran No: LB.04.01/A05/EC/291/X/2018. Peserta penelitian yang memenuhi kriteria inklusi dan tidak termasuk kriteria eksklusi diberikan penjelasan mengenai prosedur penelitian serta penandatanganan persetujuan (informed consent) pada saat preoperasi.

Pemasangan jalur intravena dengan kateter intravena ukuran $18 \mathrm{G}$ dilakukan penggantian cairan puasa sesuai dengan lama puasa. Pasien dibagi dua kelompok randomisasi secara blok permutasi dengan pemberian amplop tertutup A dan B dengan jumlah 23 per kelompok 
sampel. Pasien diinduksi secara intravena menggunakan fentanil $2 \mu \mathrm{g} / \mathrm{kgBB}$, propofol $2 \mathrm{mg} / \mathrm{kgBB}$ dan atrakurium 0,5 mg/kgBB, kemudian pasien diventilasi menggunakan gas $\mathrm{O}_{2} 50 \%$ dengan penambahan $\mathrm{N}_{2} \mathrm{O}$ dan zat anestesi volatil sevofluran 2 vol \%. Intubasi dilakukan menggunakan pipa endotrakeal dengan nomor yang sesuai. Intubasi dilakukan rumatan anestesi menggunakan gas $\mathrm{O}_{2} 50 \%$ dengan penambahan $\mathrm{N}_{2} \mathrm{O}$ dan zat anestesi volatil sevofluran $1,5-2 \mathrm{vol} \%$.

Monitoring menggunakan EKG, tekanan darah non-invasive, denyut jantung, dan saturasi oksigen. Perubahan hemodinamik dipantau setiap 5 menit sampai pembedahan selesai. Deksametason $5 \mathrm{mg}$ i.v. diberikan bolus analgetik ketorolak $0,5 \mathrm{mg} / \mathrm{kgBB}$ intravena dan petidin $0,5 \mathrm{mg} / \mathrm{kgBB}$ intravena 30 menit sebelum gas anestesi ditutup. Operasi selesai pasien lalu dipindahkan ke ruang pemulihan untuk observasi.

Kelompok A setelah pasien operasi selesai dikirim ke ruang pemulihan dan diberikan permen karet rasa mint bila terjadi mual atau menjeluak atau muntah saat pasien sudah dapat mengunyah dengan 00A/S (observer's assessment of awareness/sedation) 33 skor 5 (dapat menyebutkan nama dengan nada yang normal) di ruang PACU, permen karet dikunyah selama 15 menit, setelah itu pasien diobservasi apakah terjadi perbaikan mual atau menjeluak atau muntah setelah initial treatment.

Kelompok B setelah pasien diekstubasi dikirim ke ruang pemulihan dan diberikan obat ondansetron $4 \mathrm{mg}$ intravena setelah OAA/S 5 bila terjadi mual atau menjeluak atau muntah di ruang PACU, setelah itu pasien diobservasi apakah terjadi perbaikan mual atau menjeluak atau muntah setelah initial treatment. Pasien dapat dipindahkan ke ruang perawatan setelah memenuhi Modified Aldrette score 9-10. Keluhan nyeri dengan VAS skor $\geq 3$ diberi analgetik tambahan petidin 0,5 $\mathrm{mg} / \mathrm{kgBB}$ intravena, bila pasien tetap mual muntah setelah pemberian permen karet rasa mint atau ondansetron $4 \mathrm{mg}$ intravena maka diberi antiemetik tambahan dengan lini pertama haloperidol 0,5-2mg intravena, lini kedua deksametason $5 \mathrm{mg}$ intravena untuk menghindari rancu dari efek ondansetron sebagai salah satu obat yang akan diteliti.

Lini ketiga propofol $20 \mathrm{mg}$ intravena, kemudian pasien diobservasi dan pengamat mencatat kejadian mual muntah selama pasien di ruang pemulihan selama 2 jam. Pulih tidaknya mual muntah pascaoperasi dicatat dengan skala mual muntah. Sampel diambil dari subjek penelitian yang memenuhi kriteria inklusi. Penentuan besar sampel disesuaikan dengan tujuan penelitian, yaitu menguji hipotesis pemberian permen karet rasa mint dapat mengatasi kejadian mual muntah pascaoperasi mastektomi yang lebih banyak dibanding dengan ondansetron $4 \mathrm{mg}$ intravena.

Data hasil penelitian dilakukan pemeriksaan kelengkapan dan keakuratan data, ditabulasi diberi kode, dan dimasukkan ke dalam komputer. Analisis data dilakukan untuk mendiskripsikan variabel dependen dan independen sehingga dapat membantu analisis selanjutnya secara lebih mendalam. Selain itu, analisis secara deskriptif ini juga digunakan untuk mengetahui karakteristik subjek penelitian yang menjadi sampel penelitian.

\section{Hasil}

Hasil analisis statistika menujukkan bahwa untuk karakteristik usia, jenis kelamin, BMI, skor Apfel, riwayat gastritis, lama operasi, lama anestesi, pemberian opioid, total cairan, saturasi oksigen, dan jumlah pendarahan didapatkan hasil yang tidak berbeda signifikan ( $p>0,05$; Tabel 1).

Ditemukan perbedaan yang bermakna perbaikan yang dialami pada kelompok pasien yang diberikan permen karet rasa mint (18 pasien) dibanding dengan perbaikan yang dialami oleh kelompok pasien yang diberikan ondansetron $4 \mathrm{mg}$ intravena (hanya 9 pasien) dengan nilai $\mathrm{p}=0,017$. Waktu perbaikan mual muntah ondansetron lebih cepat (8 menit) daripada permen karet rasa mint (23 menit) dengan nilai $\mathrm{p}<0,001$. 
Tabel 1 Perbandingan Karakteristik Subjek Penelitian antara kelompok Permen Karet dan Ondansetron

\begin{tabular}{lccc}
\hline \multicolumn{1}{c}{ Variabel } & $\begin{array}{c}\text { Permen Karet } \\
\text { Rasa Mint } \\
\mathbf{n = 2 3}\end{array}$ & $\begin{array}{c}\text { Ondansetron 4mg } \\
\text { Intravena } \\
\mathbf{n = 2 3}\end{array}$ & Nilai p \\
\hline Usia & $45,2(9)$ & $41,9(10)$ & 0,247 \\
Berat badan (kg) & $58,7(5,9)$ & $58,5(6,5)$ & 0,887 \\
Tinggi badan (cm) & $158,7(3,8)$ & $158,3(4,9)$ & 0,738 \\
BMI & $23,3(2,6)$ & $22,8(2,2)$ & 0,462 \\
APFEL Skor & $2,0(0)$ & $2,0(0)$ & 1,000 \\
Gastritis & $0(0)$ & $0(0)$ & 1,000 \\
Pemberian obat anestesi intravena & & & \\
Fentanil (mcg) & $142,4(30,6)$ & $145,7(20,9)$ & 0,675 \\
Atrakurium (mg) & $47,4(6,4)$ & $49,6(6,7)$ & 0,267 \\
Propofol (mg) & $150(14,8)$ & $153,5(24,6)$ & 0,565 \\
Midazolam (mg) & $2,9(0,3)$ & $3,0(0,3)$ & 0,323 \\
Neostigmin (mg) & $0,5(0,1)$ & $0,5(0,1)$ & 1,000 \\
Sevofluran (\%Vol) & $2,3(0,5)$ & $2,3(0,5)$ & 1,000 \\
Antiemetik deksametason (mg) & $5,0(0)$ & $5,0(0)$ & 1,000 \\
Lama anestesi (menit) & $138(13,5)$ & $142,6(14,5)$ & 0,276 \\
Lama operasi (menit) & $112,8(14,4)$ & $116,1(13)$ & 0,423 \\
Jumlah pendarahan (mL) & $317,4(61,9)$ & $293,5(59,7)$ & 0,189 \\
Jumlah total cairan (mL) & $1782,6(421,7)$ & $1760,9(365,2)$ & 0,853 \\
Waktu induksi (menit) & $12(2,5)$ & $12,4(2,6)$ & 0,562 \\
\hline
\end{tabular}

Keterangan: data kategorik nilai p dihitung berdasar uji chi-square dengan alternatif Uji Kolmogorov Smirnov dan Eksak Fisher apabila syarat chi-square tidak terpenuhi. Nilai kemaknaan berdasar nilai $\mathrm{p}<0,05$.

Tanda* menunjukkan nilai $\mathrm{p}<0,05$ artinya signifkan atau bermakna secara statistik

\section{Pembahasan}

Kejadian mual muntah pascaoperasi dipengaruhi oleh faktor usia, berat badan, tinggi badan, body mass index (BMI), skor Apfel, waktu induksi, lama operasi, lama anestesi, pemberian obat anestesi intravena seperti opioid, atrakurium, propofol, midazolam dan neostigmin, penggunaan anestesi inhalasi, penggunaan antiemetik deksametason, jumlah perdarahan selama operasi, jumlah cairan selama operasi, saturasi oksigen, dan komplikasi pascaoperasi mastektomi. Faktorfaktor tersebut dapat memengaruhi renspons terhadap mual muntah. Karakteristik subjek kedua kelompok pada penelitian ini tidak berbeda bermakna ( $p>0,05)$ sehingga menjelaskan sampel penelitian pada kedua kelompok dianggap homogen dan layak untuk dibandingkan..$^{1,4}$

Gambaran penting yang didapatkan dari permen karet rasa mint dan ondansentron adalah efek mengatasi keluhan mual muntah pascaoperasi. Waktu perbaikan mual muntah pada kelompok ondansentron lebih cepat dibanding dengan kelompok permen karet. Ondansetron memiliki mula kerja kurang dari 30 menit, sebuah penelitian dilakukan pada 56 pasien untuk menilai efek farmakokinetik ondansetron $4 \mathrm{mg}$ pada pemberian bolus intravena dalam 5 menit dibanding dengan pemberian intramuskular didapatkan hasil 
Tabel 2 Perbandingan Perbaikan Mual Muntah antara kelompok Permen Karet dan Ondansetron

\begin{tabular}{llcccc}
\hline \multirow{2}{*}{ Variabel } & Kategori & $\begin{array}{c}\text { Permen Karet } \\
\text { Rasa Mint }\end{array}$ & Ondansetron & \multirow{2}{*}{ Nilai p } \\
\cline { 3 - 4 } & & $\mathbf{n = 2 3}$ & $\mathbf{n = 2 3}$ & \\
\hline Kejadian mual muntah & Mual & 7 & 7 & \\
& Menjeluak & 13 & 13 & 1,000 \\
& Muntah & 3 & 3 & \\
Perbaikan setelah initial treatment & Ya & 18 & 9 & \\
& Tidak & 5 & 14 & $0,017^{*}$ \\
Waktu perbaikan (menit) & & $23(2,4)$ & $8(2,5)$ & $<0,001^{*}$ \\
Pemberian rescue (haloperidol 5 mg i.v.) & Ya & 5 & 14 & \\
& Tidak & 18 & 9 & 0,039 \\
Perbaikan rescue (haloperidol 5 mg i.v.) & Ya & 3 & 9 & \\
& Tidak & 2 & 5 & 0,634 \\
\hline
\end{tabular}

Keterangan: untuk data-data kategorik nilai p dihitung berdasar uji chi-square dengan alternatif Uji Kolmogorov Smirnov dan Eksak Fisher apabila syarat chi-square tidak terpenuhi. Nilai kemaknaan berdasar nilai $\mathrm{p}<0,05$. Tanda* menunjukkan nilai $\mathrm{p}<0,05$ artinya signifkan atau bermakna secara statistik

konsentrasi plasma puncak tercapai hampir separuhnya $42,9 \%$ hanya dalam waktu 10 menit dari pemberian intravena. Efek sham feeding pada beberapa penelitian sampai keluarnya hormon saluran cerna yang menimbulkan efek stimulasi sefalo vagal terjadi sebelum 30 menit. Hal ini sesuai dengan penelitian sebelumnya juga didapatkan waktu perbaikan hilangnya mual muntah lebih cepat pada kelompok ondansetron dibanding dengan kelompok permen karet, tetapi jumlah pasien yang mengalami perbaikan mual muntah pada kelompok ondansentron lebih sedikit dibanding dengan mengunyah permen karet rasa mint. Hasil ini berhasil membuktikan bahwa secara statistika, mengunyah permen karet mint ternyata bermakna lebih unggul bila dibanding dengan ondansentron $(\mathrm{p}<0,05$; Tabel 2). ${ }^{2,5-7}$

Mengunyah permen karet rasa peppermint mampu menstimulasi sefalik vagal dengan memproduksi hormon gastrointestinal menyebabkan motilitas gastrointestinal serta pelepasan cairan pankreas dan saliva. Penelitian yang membandingkan efek permen karet terhadap kontrol setelah operasi kolorektal terjadi pengurangan ileus pascaoperasi yang ditunjukkan dengan waktu flatus dan waktu defekasi. Hasilnya didapatkan pemendekan waktu flatus (20 jam dengan interval kepercayaan 95\%) dan waktu defekasi (29 jam dengan interval kepercayaan $95 \%)^{8}$

Mengunyah permen karet rasa peppermint mampu menurunkan kadar kortisol, menurunkan tingkat kecemasan, dan menimbulkan perasaan bahagia menurunkan penghambat motilitas lambung serta meningkatkan volume cairan lambung. Mengunyah permen karet rasa peppermint, hal ini sejalan dengan penelitian sebelumnya bahwa permen karet tidak lebih inferior dibanding dengan ondansetron sebagai terapi PONV setelah anestesi umum pada operasi laparaskopi atau payudara pada pasien wanita. Penggunaan permen karet (wrigley's ekstra sugarfree gum $^{\circledR}$, peppermint flavour) rasa mint sebagai antimual muntah dibanding dengan ondansentron $4 \mathrm{mg}$ intravena pada operasi laparoskopi ginekologi dan mastektomi didapatkan kejadian mual muntah di ruang pemulihan $28 \%$ pada pasien 
dengan ondansentron dan $31 \%$ pada permen karet rasa mint. Resolusi mual muntah terjadi pada lima dari 13 pasien dan sembilan dari 12 pasien $(\mathrm{p}=0,07){ }^{2,5}$

Permen karet memiliki manfaat sebagai terapi mengurangi ileus paralitik sesudah operasi gastrointestinal dengan mekanisme utama "sham feeding", yaitu mengunyah dapat meningkatkan aktivitas gastrointestinal melalui stimulasi sefalik vagal. Penelitian metaanalisis dengan randomized controlled trial pada 272 pasien terjadi pengurangan waktu flatus dan gerak usus pertama kali. ${ }^{2,3,9}$

Permen karet dengan aktivitas sham feeding mengaktifasi reflek sefalik vagal yang sama dengan ketika kita memakan makanan dan menstimulasi motilitas dari duodenum, gaster, dan rektum. Permen karet meningkatkan konsentrasi gastrin serum, neurotensin dan polipeptida pankreas, menstimulasi motilitas duodenum, gaster dan rektum, serta memicu motilitas intestinal. Beberapa studi melaporkan ba hwa flatus lebih cepat terjadi waktu perawatan di rumah sakit secara signifikan berkurang pada grup permen karet, dan waktu pemulihan yang lebih cepat motilitas usus ditunjukkan pada grup permen karet. ${ }^{9}$

Keuntungan permen karet, yaitu efek samping yang hampir tidak ada, bahkan pasien yang mendapatkan permen karet rasa mint terlihat lebih nyaman. Pada beberapa penelitian sebelumnya juga didapatkan permen karet rasa mint menurunkan kejadian mual muntah seperti penelitian eksperimental randomized control trial mengenai efek permen karet terhadap efek tidak nyaman perut, mual, muntah setelah minum polietilen glikol pada pasien yang akan dilakukan kolonoskopi. Dari penelitian tersebut didapatkan hasil grup permen karet terjadi penurunan muntah yang signifikan sebesar 14\% dibanding dengan grup kontrol $(p=0,002) .{ }^{10}$

Pada penelitian mengenai peppermint didapatkan hasil pada tahap awal terjadi pengosongan lambung yang lebih cepat pada minyak peppermint dengan lag time 56,6 menit dibanding dengan kontrol 71,5 menit $(p=0,037)$. Penelitian tersebut menguatkan penelitian sebelumnya yang menunjukkan bahwa minyak peppermint dengan efek blokade kanal kalsium memengaruhi otot polos saluran cerna sehingga memengaruhi motilitas gaster dan memiliki efek antispastik pada perut. Pemberian minyak peppermint menstimulasi pembukaan cincin pilorus yang dinilai menggunakan endoskopi. ${ }^{3}$

\section{Simpulan}

Pemberian permen karet rasa mint memberikan perbaikan yang lebih banyak dalam mengatasi kejadian mual muntah pascaoperasi mastektomi dibanding dengan ondansetron $4 \mathrm{mg}$ intravena. Waktu perbaikan hilangnya mual muntah setelah perlakuan pada kelompok ondansetron $4 \mathrm{mg}$ intravena memiliki mula kerja yang lebih cepat mengatasi mual muntah dibanding dengan kelompok permen karet rasa mint.

\section{Daftar Pustaka}

1. Gan TJ, Diemunsch P, Habib AS, Kovac A, Kranke P, Meyer TA, dkk. Consensus guidelines for the management of postoperative nausea and vomiting. Anaesth Analg. 2014;118(1):85-113.

2. Darvall JN, Handscombe $M$, Leslie $K$. Chewing gum for the treatment of postoperative nausea and vomiting: a pilot randomized controlled trial. Br J Anaesth. 2017;118(1):83-9.

3. Inamori M, Akiyama T, Akimoto K, Fujita K, Takahashi H, Yoneda M, dkk. Early effects of peppermint oil on gastric emptying: a crossover study using a continuous realtime 13C breath test. J Gastroenterol. 2007;42:539-42.

4. Morgan GE, Mikhail MS, Murray MJ. Postanesthesia care. Clinical anesthesiology. Edisi ke-6. Boston: McGraw-Hill Companies; 2018.

5. Darvall J, von Ungern-Sternberg BS, Braat S, Story D, Davidson A, Allen M, dkk. Chewing gum to treat postoperative nausea and emesis in female patients (CHEWY): rationale and design for a 
multicentre randomised trial. BMJ Open. 2019;9(6):1-8.

6. Robertson MD, Jackson KG, Williams CM, Fielding BA, Frayn KN. Prolonged effects of modified sham feeding on energy substrate mobilization. Am J Clin Nutr. 2001;73(1):111-7.

7. Anderson LA, Sinha S, Durbin K, Entringer S, Stewart J, Thornton P, dkk. Ondansetron and dextrose. drugs.com [online article] 2018 [diunduh 07 November 2019]. Tersedia dari: https://www.drugs. com/pro/ondansetron-and-dextrose. html\#moreResources.

8. Chumpitazi BP, Kearns GL, Shulman RJ. Review article: the physiological effects and safety of peppermint oil and its efficacy in irritable bowel syndrome and other functional disorders. Aliment Pharmacol Ther. 2018;47(6):1-15.

9. Noble EJ, Harris R, Hosie KB, Thomas $\mathrm{S}$, Lewis SJ. Gum chewing reduces postoperative ileus? A systematic review and meta-analysis. Intern J Surg. 2009;7(2):100-5.

10. Jisun L, Eunjin L, Yumi K, Eun K, Yaera L. Effects of gum chewing on abdominal discomfort, nausea, vomiting and intake adherence to polyethylene glycol solution of patients in colonoscopy preparation. J Clin Nurs. 2016;25:518-25. 